\title{
高等教育機関における発達障害学生に対するピアサポート
}

\author{
注意欠如多動性障害学生が抱える支援ニーズに焦点を当てて \\ ○永瀬 開 \\ (山口県立大学社会福祉学部社会福祉学科) \\ キーワード : 高等教育機関 ピアサポート 注意欠如多動性障害
}

Peer Support Students with ADHD in Higher Education by Typically Students

\section{Kai NAGASE}

(Faculty of Social Welfare, Yamaguchi Prefectural University)

Key Words: Higher Education, Peer Support, Attention Deficit Hyperactivity Disorder

\section{問 題 と目的}

近年、高等教育機関における発達障害学生が増加するのに伴 い、高等教育機関における発達障害学生をどのように支援す るのかということが課題となっている（佐藤・徳永, 2006）。 発達障害学生に対する支援を考える際に、発達障害学生と同 じ高等教育機関で学ぶ障害のない学生によるピアサポートが 関心を集めている（Garrider \& Iarocci, 2014）。しかしながら、 ピアサポートを行う学生にとっても、発達障害学生が大学生 活において抱える全ての支援ニーズに対して支援を行うこと は難しいということが考えられる。なぜなら、発達障害学生 に対してピアサポートを行うことには、支援を実施するピア サポーターに対して一定の抵抗感が生じることが考えられる ためである（Nevile \& White, 2011）。この点をふまえ、本研究 では発達障害の中でも注意欠如多動性障害 (ADHD) に焦点 を当て、ADHD 学生の抱える支援ニーズに対して、大学生が どのようなニーズであればピアサポートを行うことができ、 どのようなニーズであればピアサポートを行うことが難しい と考えているのかを明らかにすることを目的とする。

方 法

対象者：四年制大学に通う51名（男性 15 名、女性 36 名）で あった。対象者の平均年齢は 20.35 歳 $(S D=0.74$; 年齢幅 $19-23$ 歳）であった。なお、本研究は山口県立大学生命倫理委員会 の承認を経て行われた（承認番号 28-29）。

質問紙 : 注意欠如多動性障害学生の支援ニーズに関するサポ 一ト項目については、「ADHD 困り感質問紙」（岩㴊・高橋, 2011；高橋, 2013）に記載されている支援ニーズをもとに作成 した。具体的には、各項目について、「あなたは以下の内容で 困っている同級生をどの程度助ける、または手伝うことがで きそうですか?」という教示を行い、4「かなり助ける（手伝 う) ことができる」、3「かなり助ける（手伝う）ことができ る」、2「あまり助ける（手伝う）ことができない」、1「全く 助ける (手伝う)ことができない」の 4 件法で回答を求めた。 手続き：それぞれの質問項目について、支援することができ ると回答した人数（質問項目において 4、もしくは 3 と回答 した人数）と支援することが難しいと回答した人数（質問項
目において 2、もしくは 1 と回答した人数）を算出し、それ ぞれの質問項目で支援することができると回答した人数につ いて、二項検定を実施した。

結 果

分析の結果、5つの項目について、支援することができると 回答した人数がチャンスレベルと比べて有意に多いことが明 らかになった。また 4 つの項目について、支援することが難 しいと回答した人数が有意にチャンスレベルと比べて多いこ とが明らかになった。分析の結果の概要を表 1 に示した。

\section{考 察}

分析の結果、「よく物をなくして困っている」、「誤解や早とち りが多くて困っている」、「新しい作業を習得するのに時間が かかってしまう」、「提出物の締め切りや期限を忘れることが あり困ってしまう」、「学校や仕事の場面で単純なミスが多く て困っている」の 5 つの項目について、大学生は支援するこ とができると考えていることが明らかになった。これらの支 援ニーズは、いずれも注意欠如多動性障害の障害特性によっ て引き起こされた「学業上の困難さ」(丹治・野呂, 2014) だ と考えられる。この結果の解釈としては、これらの「学業上 の困難さ」の支援ニーズを支援することに対する義務感の高 さと心理的負担感の低さがあると考えられる(真下ら, 2014)。

その一方で、「睡眠のリズムが不規則で困っている」、「生活 が不規則で困っている」、「授業中集中が続かなくて困ってい る」、「飽きっぽくて困っている」の 4 つの項目について大学 生は、支援することが難しいと考えることが明らかになった。 これらの内、前者 2 つが ADHD 学生の生活リズムに関わる支 援ニーズであり、後者 2 つが ADHD 学生の障害特性そのもの に関連する支援ニーズである、と考えられる。この背景とし て、前者は生活リズムを乱す大学外の要因を把握することは 大学生にとっても負担が大きいことがあると考えられ、後者 は大学生が障害特性そのものに関連する支援ニーズに対して や十分な知識を有していないことがあると考えられる。

付記 : 本研究は山口県立大学研究創作活動助成 (基盤研究型) による。

表1. 注意欠如多動性障害学生の支援二一ズ対する大学生のピアサポートに関する回答の概要

\begin{tabular}{|c|c|c|c|}
\hline 筫問項目 & $\begin{array}{c}\text { 行うことができる } \\
\text { と回答した人数 }\end{array}$ & $\begin{array}{c}\text { 行うことが困難だ } \\
\text { と回答した人数 }\end{array}$ & 有意確率 \\
\hline 2. 睡眠のリズムが不規則で困っている & $13(25.5 \%)$ & $38(74.5 \%)$ & $\rho<0.01$ \\
\hline 3. よく物をなくして困っている & $34(66.7 \%)$ & $17(33.3 \%)$ & $p<0.05$ \\
\hline 4. 悞解や早とちりが多くて困っている & $35(68.6 \%)$ & $16(31.4 \%)$ & $\rho<0.05$ \\
\hline 7. 生活が不規則で困っている & $17(33.3 \%)$ & $34(66.7 \%)$ & $\rho<0.05$ \\
\hline 8. 授業中集中が続かなくて困っている & $12(32.5 \%)$ & $39(76.5 \%)$ & $p<0.01$ \\
\hline 9. 飽きっぽくて困っている & $12(32.5 \%)$ & $39(76.5 \%)$ & $\rho<0.01$ \\
\hline 13. 新しい作業を習得するのに時間がかかってしまう & $35(68.6 \%)$ & $16(31.4 \%)$ & $p<0.05$ \\
\hline 15. 提出物の締め切りや期限を忘れることがあり困ってしまう & $40(78.4 \%)$ & $11(21.6 \%)$ & $p<0.01$ \\
\hline 16. 学校や仕事の場面で単純なミスが多くて困っている & $34(66.7 \%)$ & $17(33.3 \%)$ & $p<0.05$ \\
\hline
\end{tabular}

